\title{
Metafizička okrenutost drugomu kao temelj političkoj ideji zajedništva
}

\author{
Goran SUNAJKO - RATKo PODVORAC* \\ UDK: 14:32 • Izvorni znanstveni rad \\ Primljeno: 4. listopada 2016. • Prihvaćeno: 13. lipnja 2017.
}

\footnotetext{
* Doc. dr. sc. Goran Sunajko, Leksikografski zavod Miroslav Krleža, Frankopanska 26, 10000 Zagreb, Hrvatska; naslovni docent na Filozofskom fakultetu Sveučilišta u Zagrebu, Ivana Lučića 3, 10000 Zagreb, Hrvatska, goran.sunajko@lzmk.hr

Ratko Podvorac, mag. theol., postdiplomand, Katolički bogoslovni fakultet Sveučilišta u Zagrebu, Vlaška 38, 10000 Zagreb, Hrvatska, diaconusrp@gmail.com
}

Sažetak: Cilj je rada razmotriti važnost metafizike za pitanja dobra i prijateljstva kao preduvjeta društvenoga i političkoga zajedništva. Vidljivo je da je danas ideja prijateljstva ozbiljno narušena interesnim i egoističnim postulatima utemeljenima na materijalnoj egzistenciji, stoga je potrebno pitanje o egzistenciji postaviti u njezine metafizičke okvire okrenutosti prema drugomu, što je temeljni supstrat kršćanske metafizike oslonjene na Platonove i Aristotelove postulate. Rad će se usredotočiti na Platonove, Aristotelove, Augustinove i Tomine uvide kojima se otvara mogućnost mišljenja Drugoga kao preduvjeta filozofije i politike prijateljstva. Cilj je rada samo naznačiti neke odnose koji spajaju metafizičke i političke uvide o važnosti ideje dobra i prijateljstva kao preduvjeta otvorenosti prema drugima i time mogućnosti ostvarenja bilo kakvoga oblika zajedništva.

Ključne riječi: Platon, Aristotel, Augustin, Toma Akvinski, dobro, prijateljstvo, egoizam, politicka zajednica.

\section{Uvod}

Mogu li metafizika i politika, odnosno kršćanska teologija i politika biti postavljene $u$ istu rečenicu? Nije li teologija per se nešto sasvim oprečno pojmu političkoga, napose modernoga? Na sva ta pitanja nije moguće odgovoriti na jednome mjestu, no ovdje nastojimo pokazati samo dio tradicije mišljenja koja pokazuju kako je jaz između metafizike, pa i religije, s jedne strane te politike $s$ druge strane daleko manji nego što navedena pitanja sugeriraju. Treba, dakako, imati na umu da je metafizika temeljna filozofska 
disciplina koja pita o prvim počelima svijeta, a religija sustav vjerovanja u nadnaravno. Veže ih, prije svega, to da im je physis, kao ono prolazno, tek sekundarnoga značenja. No politika prema Aristotelovoj razdiobi pripada u praktične discipline, a to znači u one kojima je physis imanentan, stoga se ono političko odvija u vremenu i prostoru, odnosno u ovostranome te podliježe njegovim zakonitostima. Političkom je svijet horizont, rekli bismo, a metafizici i religiji ono prekosvjetovno, transcendentno. Kako je uopće moguće pomiriti transcendenciju i imanenciju ljudske egzistencije kada su se filozofski sustavi često okretali jednomu ili drugomu ekstremu?

\section{Platonov pojam dobra i Aristotelov pojam prijateljstva}

No ako se zadržimo na antičkoj filozofiji, onda je ono političko, kao i sve praktično, odslika onoga kozmološkoga (metafizičkoga) jer harmonia koja određuje kozmos treba biti ono na što se ugleda ono niže, praktično, u uređenju svojega svijeta života. Kozmos je tako uređen u jedinstvu, skladnosti i ravnoteži, stoga za Platona poredak čuvara polisa odgovara poretku ravnoteže dijelova duše. Leo Strauss sugerira kako su Platonova djela Država, Državnik i Zakoni temeljna politička djela u kojima se raspravlja politika, odnosno dobro i pravedno uređenje, odnosno politeia, no ona se ne mogu sagledavati odvojeno od ostalih, napose kozmoloških djela. ${ }^{1}$ Tako se primjerice središnje mjesto kozmološkoga djela Timaj, demijurg, spominje i u Drža$v i{ }^{2}$ Dakako, ne slučajno, već s važnošću političkih implikacija po politički poredak utemeljen u božanskoj savršenosti očitovanoj u nousu kao pretpostavci okrenutosti mudrosti (sophia) i razboritosti (phronesis) koje trebaju imati upravljači polisa. $\mathrm{Na}$ isti način u Državi Platon pokazuje kako se budući mudri vladar ne usavršava po uzoru na sebe i iz sebe, nego po uzoru na ideje kao ono vječno, božansko što je čovjeku nužno transcendentno, kao izvanjsko. Samo je tvorac, demijurg, oblikovao kozmos prema vlastitom uzoru i slici jer je sam sadržaj Dobra što pretpostavlja da je djelovanje svakoga u skladu s tim jedino poželjno i ispravno postupanje. »Onaj koji bi ovo od najrazboritijih ljudi preuzeo kao vrhovno načelo postajanja i kozmosa, prihvatio bi upravo ono šta je najispravnije. $\ll^{3}$ Međutim, ono što također određuje Platonovu misao jest to da se do onoga transcendentnoga i po uzoru na njega može samo filozofijom, a filozof kralj time postaje onaj koji nadmašuje ostale te koji je

\footnotetext{
${ }^{1}$ Usp. L. STRAUSS, J. CROPSEY, Povijest političke filozofije, Zagreb, 2006. Barbarić također pokazuje kako je u Platona svaki, pa i naoko najbeznačajniji, teorijski stav vođen, usmjeren i motiviran politički. Stoga se pravi smisao njegovih političkih stavova može shvatiti samo na podlozi prethodnoga uvažavanja trojnoga paralelizma bivanja kozmosa, duše i polisa. Usp. D. BARBARIĆ, Hrestomatija filozofije I: Grčka filozofija, Zagreb, 1995., 103.

${ }^{2}$ Usp. PLATON, Država, Zagreb, 1997., 286.

${ }^{3}$ PLATON, Timaj, Beograd, 1981., 70.
} 
okrenut samome sebi i kontemplativnom, teorijskom kojima doseže blaženstvo, iz čega izostaje mišljenje onoga drugoga. Riječ je o onome što Hannah Arendt primjećuje kao »autoritet « filozofa nad polisom, koji međutim gubi orijentaciju u ljudskim poslovima. ${ }^{4}$ Zbog toga je put otvoren, pokazuje u Fedonu, jedino filozofima jer »u kolo božje ne smije nitko, ako se nije bavio filozofijom i ne ode sasvim čist; samo znanja željnu slobodno je onamo $\ll^{5}$ Odnosno, kao središnje mjesto te argumentacije Platon izlaže vjeru u odnos filozofije i politike koji će u novom vijeku biti napušten:

$\gg$ Ako, ili filozofi ne postanu u državama kraljevi, ili sadašnji kraljevi i vladari ne postanu filozofi istinski i potpuno, i ako se to oboje ne složi u jedno, naime državna vlast i filozofija, te ako od onih, koji sada odijeliti slijede bilo jedno bilo drugo, svi ne budu prisilno odalečeni od vlasti, onda neće, mili Glaukone, prestati zlo u državama, a mislim ni u rodu ljudskome. To državno uređenje, koje smo sada raspravili neće se zaista nikada prije moći ostvariti ni svjetlo sunčano ugledati. $\ll^{6}$

Odlučujuće je to da Platon tu okrenutost sebi ublažava na kraju rasprave u Državi pokazujući da onaj vladar koji se ugleda na boga ne će raditi u svoju korist, već radi pravednosti, no takvoga nema u onoj državi u kojoj se rodio, osim ako se ne dogodi kakav znak od boga. Na pitanje kako je takvo što moguće samo u zamišljenoj (idealnoj) političkoj zajednici koje nema na zemlji, nego samo u mislima, Platon ostavlja nadu jer »(...) možda je na nebu kao uzor za onoga, koji je hoće vidjeti i videći nju sebe uređivati $(. . .)_{\text {« }}{ }^{7}$. U Državi Platon odlučujuće pokazuje kako je kozmološki postavljena pravednost u temelju prijateljstva bez kojega polis nije moguć kao jedno »jer nepravda Trazimaše, uzrokuje međusobno razdor, mržnje i borbe, a pravednost slogu i prijateljstvo $(. ..) \ll^{8}$. Hannah Arendt pokazuje, a za našu je tezu relevantno, kako je »Platon prvi koji se usprotivio političkoj 'neprimjenjivosti' svojega novog učenja, pa je učenje o idejama pokušao oblikovati tako da bi moglo postati korisno za političku teoriju « ${ }^{9}$. Nastavlja kako je takva upotrebljivost moguća samo, kao što pokazujemo ovim radom, u ideji dobra jer dobro u grčkom rječniku znači uvijek dobro za ili prikladno.

\footnotetext{
${ }^{4}$ Usp. H. ARENDT, Politički eseji, Antibarbarus, Zagreb, 1996., 25.

${ }^{5}$ PLATON, Fedon, Zagreb, 1996., 79. Također u Državi Platon piše: »Družeći se dakle filozof s božanskim i urednim postaje božanski i uredan, koliko kao čovjek može (Platon, Država, 252.).

${ }^{6}$ Isto, 222.

${ }^{7}$ PLATON, Država, 365.

${ }^{8}$ Isto, 74.

${ }^{9}$ H. ARENDT, Politički eseji, 29.
} 
U konačnici, potvrdu važnosti čovjekova okretanja izvanjskome, kao onomu što tek omogućuje pravednu egzistenciju, Platon pokazuje na kraju svoga puta u $\mathrm{Za}$ konima postavljajući poziciju nomokracije, odnosno vladavine zakona, a ne ljudi. Zakon, kao sadržaj pravednosti, sada postaje čovjeku nužna izvanjskost. Zakoni će $\gg$ u nekim slučajevima nagovarati, a gdje se ćudi ne daju nagovorom skloniti, silom i pravom kažnjavati, te uz naklonost bogova učiniti našu državu blaženom i sretnom $\ll^{10}$. Arendt pokazuje kako su u Platona ideje upravo primjenjive i one to postaju u rukama stručnjaka za ideje, filozofa, filozofa kralja. One to postaju kao norme i kasnije u Zakonima, kao što smo pokazali, zakon kojega se ljudi pridržavaju kao onoga izvanjskoga sebi, božanskoga. »Prava posljedica ovog političkog tumačenja učenja o idejama bila bi da ni čovjek ni bog nisu mjera svih stvari, već sâmo dobro - posljedica koju je očito Aristotel, a ne Platon, izveo u jednom od svojih najranijih dijaloga. ${ }^{11}$

Aristotel će preuzeti kozmološki postulat težnje dobru jer sve postoji zbog neke svrhe, no više će biti okrenut ideji prijateljstva koja po sebi pretpostavlja onoga drugoga te će, za razliku od Platona, biće razmatrati kao mnoštveno. Također je bitno istaknuti kako se ni Aristotelova praktična djela, poput Politike i Nikomahove etike, ne mogu razmatrati odvojeno od njegove Metafizike. Odnosno, »Aristotelovo normativno određenje biti i svrhe države nošeno je metapolitičkim karakterom Aristotelovih osnovnih političkih kategorija, ili, drugačije rečeno, osnovne političke kategorije utemeljene su u metafizici ${ }^{12}$. Kada govori o najvišoj znanosti ističe da je »najpodobnija vladati ona koja zna poradi čega treba činiti svaku stvar, a to je Dobro svake pojedinosti i u cijelosti ono Najbolje u cjelokupnoj naravi $\ll{ }^{13}$. Nadalje nastavlja da ta (znanost) mora biti znanstveno istraživanje prvih počela i uzroka jer dobro i ono zbog čega jest jedno od uzroka kao causa finalis. Tako ono prvo koje pokreće (metafizika) mora biti drukčije po naravi od onoga što je pokretano (fizika). Svakako uzrok mora biti nešto prvo i postoji kao nešto što se kreće neprekidnim kružnim kretanjem.

»I budući je stvar koja se kreće nešto srednje jest i nešto koje pokreće a nije pokrenuto, i koje je vječno, bivstvo i djelatnost. Tim načinom pokreće ono što je žudljivo i spoznatljivo, jer nepokrenuti pokreću. $\ll^{14}$

\footnotetext{
${ }^{10}$ PLATON, Zakoni, Zagreb, 1974., 162.

${ }^{11}$ H. ARENDT, Politički eseji, 29. Arendt piše kako Platonov novi teološki Bog nije ni živući Bog ni bog filozofa, ni pogansko božanstvo; on je politički izum, mjera svih mjera, to jest norma prema kojoj bi se mogli osnivati gradovi i postavljati pravila ponašanja za mnoštvo. Usp. isto, 47.

${ }^{12}$ Z. POSAVEC, Značenje Aristotelove Politike, u: ARISTOTEL, Politika, Zagreb, 1988., 5.-30., 22.

${ }^{13}$ ARISTOTEL, Metafizika, Zagreb, 1988., 5.

${ }^{14}$ Isto, 304.
} 
Time to središnje mjesto Aristotelove Metafizike određuje da se sve ono tvarno i prolazno usmjerava prema onom savršenijem i vječnom. Odnosno, da se svaka pojedinačnost snagom atributa onoga bića (ens), jednoga (unum), dobroga (bonum), istinitoga (verum) i lijepoga (pulchrum) njemu okreće i njima postaje kao savršenijim privučeno. Sve ono tvarno u što pripada i čovjek ima svoju izvanjsku svrhu jer se, dakako, ništa ne kreće niti uzrokuje samo sebe, osim onoga prvoga, što će biti i temelj kršćanske metafizike, osobito Tomina i Dunsova skolasticizma.

Transformacija tih metafizičkih postulata vidljiva je u političkim i etičkim spisima jer se u njima očituje mnoštvenost bića te njihova nužna svrhovita izvanjskost kao upućenost na druge. Najizraženija je u postulatu o čovjeku koji je po naravi zoon politikon te u pojmu prijateljstva koji pretpostavlja mnoštvenost, što je utemeljeno u Metafizici. Aristotel tako svoju filozofiju politike u Politici utemeljuje u fizičkim i metafizičkim temeljima prema kojima je cjelina ništa više nego sastavina svojih dijelova, »jer kao što u ostalim stvarima složevinu treba razdijeliti sve do nesloževinâ (budući da su oni najmanji djelići cjeline), tako i o gradu, razmatrajući iz kojih je dijelova složen, uvidjet ćemo i o tima bolje u čemu se razlikuju jedni od drugih, i ako se štogod znanstveno može postaviti o svakom pojedinome od rečenog ${ }^{15}$. Posavec primjećuje da se povijesni prikaz odnosa domaćinstva i države odvija iz metafizičke ravni i može se ispravno razumjeti samo s pomoću Metafizike. Država (polis) tako prema prirodi opstoji prije nego domaćinstvo, ali prema povijesnom nastanku i empiriji ona je nastala kasnije. Taj stav moguće je razumjeti jedino iz tijesne povezanosti Politike i Metafizike, stoga misao o prioritetu polisa i podjelu na domaćinstvo i državu, zadobivenu na kategorijalnom sklopu Metafizike, Aristotel oštro suprotstavlja Platonu i Ksenofonu, koji ne razlikuju veliko domaćinstvo i malu državu. Platon je smatrao da postoji jedna jedinstvena tehnika vladanja u obama područjima tako da se vlast kralja i gospodara domaćinstva ne razlikuju. ${ }^{16}$ Pretpostavka dioništva građana u političkome zajedništvu jest čovjekova društvena i politička narav i on ne može bez političke zajednice, odnosno u njoj se ostvaruje svrha njegova života, stoga je »bjelodano kako je grad jedna od naravnina, i da je čovjek po naravi društvena životinja, i onaj koji je bez grada - zbog naravi a ne zbog slučaja - ili je nevaljao ili je bolji od čovjeka $(. ..) \ll{ }^{17}$.

Takvo razumijevanje politike po uzoru na metafizička načela dobra s jedne strane bit će utemeljena i u etici s druge strane kao horizontalnom odnosu dijelova polisa, kao i dijelova kozmosa koji treba biti u harmoniji. Pojam prijateljstva kao nužne drugotnosti u temelju je samoga bića. Pitanje dobra i prijateljstva, odnosa koji se

\footnotetext{
${ }^{15}$ ARISTOTEL, Politika, 2.

${ }^{16}$ Usp. Z. POSAVEC, Značenje Aristotelove Politike, 16.

${ }^{17}$ ARISTOTEL, Politika, 4.
} 
stvaraju u povijesnim okvirima jest ono što na određeni način definira politiku postavljajući joj određene zahtjeve. Istražujući Aristotelovu misao otkrivamo politiku kao odnos. Znakovito je da je antička misao, napose Aristotelova, u znanosti o političkom zajedništvu, tj. politici, kao osnovni motiv državotvornosti ${ }^{18}$ imala odnos prijateljstva utemeljen na ljubavi. Aristotel će u Nikomahovoj etici potvrditi svoje mišljenje da svako stvaranje u umjetnosti i istraživanje u znanosti teži nekom dobru, dobro je ono prema čemu sve teži, čime se etika zajedno s politikom u potpunosti poklapa s metafizikom jer je, kako piše:

»svako zajedništvo poradi nekog dobra (jer radi onoga što im se čini dobro, svi čine sve), bjelodano je da sva zajedništva teže nekom dobru, a najviše pak i onomu koje je najpoglavitije od svih dobara, ono zajedništvo koje je od svih najpoglavitije i u sebi sadržava ostala. A to je ono nazvano država i državno zajedništvo. ${ }^{19}$

Ono je upućeno na mnoštvenost i time prijateljstvo kao nužnost jer »ne sastoji se država samo od mnogih ljudi nego i od onih koji se vrstom razlikuju. Jer država ne nastaje od sličnikâ $\ll^{20}$. Kada bi država bila jedno, kako to pokazuje Sokrat odnosno Platon, onda više ne bi bilo riječi o državi, nego o njezinoj suprotnosti, odnosno o izopačenosti u negativni poredak tiranije u kojem više nema prirodne podjele vladanja i pokoravanja.

Pojam vrline (arete) odlučujući je kao samo središte Aristotelova etičkoga istraživanja jer je usko povezan s prijateljstvom kao nužnom drugotnosti. Možemo reći da razumijevanje Aristotelove etike uvelike ovisi o razumijevanju pojma i stvarnosti vrline koja nije nastala iz metafizičkoga promišljanja, nego iz čovjekove nutrine, no koja ipak mora biti u skladu s metafizičkim odnosima kozmosa. Teorija vrlina, koja čini većinu Aristotelova istraživanja, čini dio obuhvatnije teorije ljudskoga djelovanja. U drugoj knjizi Nikomahove etike u podjeli vrlina na intelektualne i moralne pokazuje kako moralne vrline nisu urođene, nego su sposobnosti koje čovjek može steći vježbom. Vrlina se ostvaruje vježbom pa je i njezin razvoj određeno postignuće koje se može steći ustrajnim, odnosno aktivnim radom. ${ }^{21}$ Prestankom vježbanja gubi se vrlina. Područje na kojem uvježbavamo vrline u odlučnom su smislu naši

\footnotetext{
${ }^{18}$ Treba imati na umu da je antički i srednjovjekovni termin država pogrešan jer ona kao pojam i oblik političke zajednice postoji tek od novoga vijeka.

${ }^{19}$ ARISTOTEL, Politika, 1.

${ }^{20}$ Isto, 30.

${ }^{21}$ Hannah Arendt će, uvelike pod utjecajem Aristotelova nauka o vrlinama te Augustinova pojma ljubavi, na kojem je i doktorirala kod Jaspersa, pisati kako se mišljenje uči ustrajnim vježbanjem. Ono nije danost koje bi bilo čista vita contemplativa isključena iz aktivnoga djelovanja. Usp. H. ARENDT, Vita activa, Zagreb, 1991.
} 
postupci u odnosima prema ljudima. Stoga je kontekst vrline čovjekovo djelovanje prema drugima.

Aristotelova etika jest dio praktične filozofije zajedno s politikom jer se čovjekovo dobro kao vrijednost može ostvariti samo djelovanjem u političkoj zajednici. Cilj morala nije u teoretskoj spoznaji, nego u postajanju dobrim, što upućuje na proces na isti način kao što je u Metafizici dobro počela o nastajanju i kretanju. ${ }^{22}$

Kratko razmatranje metafizičkih (kozmoloških) postulata nužne okrenutosti transcendentnom (izvanjskom) Dobru kao onomu drugomu tek omogućuje pojam prijateljstva koji je u Aristotela utemeljen najprije u Metafizici, ali samo u smislu kozmičkih odnosa. U Nikomahovoj etici Aristotel pokazuje prijateljstvo kao vrlinu jer nitko ne bi izabrao živjeti bez prijatelja, pa čak kad bi imao i sva ostala dobra. U političkom smislu »čini se da prijateljstvo održava države, te se i zakonodavci više trse oko njega negoli oko pravednosti; naime, čini se kako je složnost nešto nalik na prijateljstvo, a ona je ono čemu najviše teže, dok izgone nesložnost, koja je najveći neprijatelj $\ll^{23}$. Odlučujuće je to i po prikaz važnosti konstituiranja političke zajednice da je prijateljstvo supstrat političkoga zajedništva, čak iznad pravednosti. Dakako, u idealnim uvjetima, što je teško postići. Naime, »kad su ljudi prijatelji ne treba im pravednosti; dočim kad su pravedni, treba im prijateljstva. I od pravednih stvari čini se da je najviše tako ono što je prijateljstvo $\ll^{24}$.

Dimenzija prijateljstva međutim sadrži u sebi različite probleme. Neki ga smatraju utemeljenim na jednakosti i sličnostima koje se privlače. Postoje stajališta koja ne prihvaćaju to načelo, nego ga nalaze u suprotnostima koje su nužne da bi se stvari privukle, kao kod Heraklita, te je onaj sklad što nastaje iz različitosti baš ono što je lijepo. Da bi razumio prijateljstvo, Aristotel istražuje ono što se tiče čovjekova karaktera i načina osjećanja.

Međusobna privlačnost među ljudima ovisi o onom što uopće može biti predmet ljubavi, a ljubiti se može samo ono što je vrijedno ljubavi. Tri su vrijednosti, prema Aristotelu, vrijedne ljubavi: ono dobro, ugodno i korisno. Korisno nam je sredstvo za stjecanje dobroga i ugodnoga. Stoga ono što je predmet ljubavi jest ono što je dobro i ugodno. Iz toga se postavlja pitanje dobroga uopće ili dobroga za pojedinca. Pojmom ljubavi može se koristiti samo onda kada je u uzvraćanju, dakle među živim bićima. Prijatelju se želi dobro zbog njega samoga. Tek se uzvraćena naklonost naziva prijateljstvom. Prijateljstvo teži za odgovorom na prvotnu dobronamjernost, stoga je za prijateljstvo nužno da u međusobnom odnosu postoji odgovor

\footnotetext{
${ }^{22}$ Usp. ARISTOTEL, Metafizika, 86.

${ }^{23}$ ARISTOTEL, Nikomahova etika, Zagreb, 1992., 156.

${ }^{24}$ Isto.
} 
na nečiju dobrohotnost. Premda motivi za ljubav moraju postojati, mora postojati i ono što pokreće na ljubav, a to je uzajamna naklonost očitovana s obiju strana. Uvjet za prijateljstvo jest uzvraćena ljubav koja je očitovana i koju su prepoznala oba sudionika u aktivnom odnosu. Već se vidi da je u prijateljstvu prisutna i vrlina pravednosti.

Iz različitosti motiva osobne naklonosti razlikujemo i vrste prijateljstva. ${ }^{25} \mathrm{Iz}$ tri temeljna motiva postoje i tri vrste prijateljstva. Iz koristi se ostvaruje onakvo prijateljstvo iz kojega se za obje strane ostvaruje neko dobro utemeljeno na obostranoj koristi. U temelju je toga odnosa osobna korist, stoga u središtu njihova odnosa nije drugi sa svojim osobnim kvalitetama. Odnos slabi ili prestaje onda kada nestaje potreba za korišću. Druga je vrsta prijateljstva utemeljena na užitku koji si korisnici međusobno pružaju. Budući da se takva vrsta prijateljstva prepoznaje kod mladih, jer slijede svoje strasti i trenutak, prijateljstva se brzo i lako prekidaju. Treća je vrsta prijateljstva savršeno prijateljstvo. Ono veže »dobre ljude sličnih moralnih kvaliteta $\ll^{26}$. Dobro koje se želi prijatelju u tom slučaju želi se zbog njega samoga. U savršenom je prijateljstvu razlog prijateljstva u odnosu prema dobroti osoba koje su na određeni način slične moralnoj dimenziji onoga koji traži to prijateljstvo. Iz toga slijedi da je intenzitet odnosa koji među njima postoji vrlo snažan. Savršena prijateljstva zahtijevaju vrijeme i iskustvo života provedenoga zajedno u dobru i zlu, a s obzirom na zahtjeve koje postavljaju i vrijednosti koje imaju, rijetko se sreću. Savršeno prijateljstvo naziva se i najvišim prijateljstvom jer je i vrijednost koja je uključena u njega najviša, a to je apsolutno dobro. Ono se ostvaruje među dobrim ljudima, stoga je dobar čovjek najveće dobro dobrom čovjeku. Dobar čovjek istovremeno je i ugodan i koristan. Vrijednost ili kvaliteta prijateljstva određuje se prema vrlini koju ima u središtu i oko koje gradi međusobni odnos. $S$ toga stajališta oni odnosi koji se mogu nazvati prijateljstvom, s obzirom na korist i užitak, ne moraju se nužno oblikovati među jednakima, nego mogu i među nejednakima, zbog čega ih se i ne mora nazivati prijateljstvom u strogom smislu te riječi. ${ }^{27}$

Ono što nas osobito zanima jest prijateljstvo u društvenom smislu, odnosno na razini političke zajednice, koje Aristotel zasebno razmatra. Prijateljstvo se, kao društvena dimenzija, očituje u svakom komunitarnom principu ljudskoga postojanja. Udruživanje je dimenzija ljudskoga postojanja i njegova načina života, a svrha mu je dobro življenje. Stoga državna zajednica kao sastavne dijelove ima elemen-

\footnotetext{
${ }^{25}$ Usp. isto, 158.-159.

${ }^{26}$ Isto, 160.

${ }^{27}$ Prijateljstvo, nadalje pokazuje Aristotel, ne postoji samo između jednakih. Oblici prijateljstva postoje i između nejednakih, primjerice kada je jedna strana moćnija od druge (otac - sin, muž - žena, vladar - podanik).
} 
te udruživanja radi postizanja ljubavi. Udruživanje je motivirano nekom korišću. Tako je i državna zajednica od samoga početka potaknuta korišću, što čini osnovu i samoga zakonodavstva. Aristotel stoga određuje pojam prijateljstva s obzirom na vladavinske oblike. Tri temeljna i pozitivna državna uređenja (kraljevstvo, aristokracija i politeia) zajedno sa svojim suprotnostima (tiranija, timokracija i demokracija) pretpostavljaju i tipove odgovarajućih vrsta prijateljstava. Odnos kralja prema podanicima naglašen je kao odnos dobročinstva kralja prema svom narodu. Odnos oca prema djetetu sličan je onomu kralja i podanika, samo smanjenoga opsega. Odnos između muškarca i žene izjednačen je s odnosom u aristokraciji jer je mjerilo i toga odnosa vrlina. Prijateljski odnos među braćom sliči onom u kojem postoji jednakopravnost i ravnopravnost.

Svaka od triju mogućnosti prijateljstva ima dva vida: 1) oba su subjekta jednaka u vrlini ili koristi koju međusobno ostvaruju, 2) jedna je strana moćnija od druge. Jednakost je kriterij za obje strane, a oni koji su jednaki trebaju je održavati, dok se oni slabiji u vrlini trebaju potruditi da bi dostigli razinu vrline onoga koji je moćniji u ljubavi. Prijateljstvo obuhvaća dvije strane koje su obje spremne ulagati i davati u vezu bilo da je motiv zajedništva korist, užitak ili samo dobro. Razmatranja Dobra, prijateljstva, odnosno ljubavi zadobit će sasvim drukčiju dimenziju razvojem kršćanske metafizike, napose Augustinove.

\section{Dobro i prijateljstvo kršćanske metafizike}

Dolaskom kršćanstva dolazi do prilagodbe antičke filozofske misli kršćanskoj. Leff pokazuje kako trebati uzeti u obzir nekoliko temeljnih razmatranja koja kršćanski filozofi nisu mogli preuzeti iz ranijih postulata. Prvo, shvaćanje Boga koji je iznad svega, za razliku od ranijih razmatranja u kojima je bio ograničen na Dobro ili pravednost, stoga je središnjim postao biblijski personificirajući moment: Ja sam koji jesam. Drugo, pretvaranje filozofije u filozofiju stvaranja (kreacije), odnosno postulata Providnosti kao središnjega postulata. I treće, (za razliku od antičkih kozmoloških razmatranja koja ne uzimaju u obzir pojam vremena) uvođenje pojma vremena, odnosno početka, sredine i kraja zbivanja, od Božje kreacije, preko putovanja ovim svijetom, do sudnjega dana i kraljevstva nebeskoga. ${ }^{28}$ Nužno je razumjeti da je kršćanstvo prvih vremena bilo izrazito eshatološko. Isusov se povratak u slavi očekivao vrlo brzo, još za života prvih sudionika. Taj je mentalni kontekst omogućavao prilično radikalan odnos prema ovozemaljskom životu koji je u osnovi bio bdijenje i iščekivanje Isusova dolaska u slavi. Budući da se povijesna stvarnost pokazala drukčijom, trebalo je dati odgovor na pitanje kako živjeti u poganskom okruženju.

${ }^{28}$ Usp. G. LEFF, Medieval Thought St. Augustine to Ockham, Baltimore, 1958., 17.-18. 


\subsection{Augustinov dualizam ljubavi}

Aurelije Augustin svoje metafizičke postulate razmatra upravo nakon pada Carstva kada se kršćane optužuje za dekadenciju. Augustin zadržava Platonov nauk o idejama i dobru kao nepromjenjivom, no također napušta platonizam u postulatu stvaranja. ${ }^{29} \gg$ Nisi naime radio kao čovjek umjetnik, koji oblikuje jedno tijelo od drugoga tijela po volji duše koja može nametnuti na bilo koji način onaj oblik koji vidi u samoj sebi unutarnjim okom - a odakle bi to mogla da je nisi ti stvorio? « ${ }^{30}$

Vidljivo je, dakako, njegovo obraćanje Bogu u prvom licu kao čin personalizacije koja je nedostajala antičkoj metafizici. Odlučujući pojam jest pojam volje koji kod Augustina jamči pojam slobode jer će sama volja omogućavati čovjeku jedini put do Boga kojega se ne može spoznati osjetilima ili umom, nego samo volje-ti ljubljenjem vrhovnoga Dobra. Otuda se do Boga kao onoga Drugoga dolazi ljubavlju. ${ }^{31}$ Univerzalnost Boga, suprotno antici, temeljna je Augustinova premisa jer je sada Božja volja djelovati erga omnes kao kolektivno mjesto općenite pravednosti. Ona je općenita jer se izdiže iznad partikularnosti i pojedinačnosti, a opća je jer vrijedi na opći način, prema svima. Pravednost Boga kao njegova temeljna zakonitost tako više nije ona koja vrijedi za jedan polis, a za drugi ne, kako je smatrao Aristotel, nego je »uređujući običaje zemalja i vremenâ kako odgovara zemljama i vremenima, taj zakon svugdje i uvijek isti, a ne ovdje ovakav, ondje onakav, danas ovakav, sutra onakav «. ${ }^{32} \mathrm{U}$ svom najznačajnijem djelu $O$ državi Božjoj Augustin piše o dvama radikalno različitim društvima utemeljenima na dvjema oprečnim voljama. Ona volja koja je usmjerena na zemaljsko stvara građanina ovoga svijeta. Drukčiji je građanin čija je volja usmjerena prema Božjem gradu. Iz toga nastaju dvije države, ona zemaljska, civitas terrena, koju simbolizira Babilon i ona božanska, civitas Dei, koju simbolizira Jeruzalem. Svaka je od njih utemeljena na jednoj od ljubavi. Iz te osnovne podjele Augustin razlikuje i dvije ljubavi koje su motiv nastanka tih dviju država. Zemaljska država utemeljena je na sebičnoj ljubavi kojoj je u središtu čovjek i njegov užitak do mjere odbacivanja Boga. Nebeska je država, posve suprotno, motivirana ljubavlju koja prezire sebe, a u središte stavlja Boga i njegove zapovijedi. $\mathrm{Na}$ isti se način dijeli i građanstvo. Ono zemaljsko navlači prijezir i osudu Božju jer odbacuje Boga i njegov zahtjev za nesebičnom ljubavlju. Nebesko građanstvo

\footnotetext{
${ }^{29}$ Augustin svoju inspiriranost Platonom pokazuje time što primjećuje kako »neki koji su s nama združeni u Kristovoj milosti čude se kad čuju ili pročitaju da je Platon o Bogu mislio isto ono što prepoznaju kao uvelike sukladno istini naše vjere«; AURELIJE AUGUSTIN, O državi Božjoj, I, Zagreb, 567.

${ }^{30}$ AURELIJE AUGUSTIN, Ispovijesti, Zagreb, 2002.

${ }^{31}$ AURELIJE AUGUSTIN, O slobodi volje, Zagreb, 1998.

${ }^{32}$ AURELIJE AUGUSTIN, Ispovijesti, 46.
} 
donosi blagoslov jer izrasta na odnosu ljubavi prema Bogu. ${ }^{33}$ Prva, sebična ljubav proizvela je zemaljsku državu i sve iskvarene vrijednosti koje ju utemeljuju, a druga Božju državu, koju odlikuje pravednost i dobrota usmjerena svima, i stoga je vječno održiva.

$\gg$ I tako su dvije ljubavi stvorile dva grada: zemaljski grad ljubav prema sebi, sve do prezira Boga, i nebeski grad ljubav prema Bogu, sve do prezira sebe. Pa se stoga zemaljski grad slavi u sebi samome, a nebeski u Gospodinu. Prvi traži slavu od ljudi, dok je drugome najveća slava Bog, svjedok savjesti (...). U prvome gradu, žudnja za vladavinom vlada knezovima kao i narodima koje svladava; u drugome služe jedan drugomu u ljubavi i pretpostavljeni savjetom i podređeni posluhom. $\ll^{34}$

U polemici s Ciceronom Augustin pokazuje zbog čega politička zajednica treba biti okrenuta kršćanskim, metafizičkom načelima.

»Zbog toga, ondje gdje nema te pravednosti, po kojoj bi jedan i najviši Bog prema milosti svojoj vladao poslušnim gradom, tako da taj ne žrtvuje nikomu osim samo njemu (i prema tome, u svim ljudima što pripadaju dotičnome gradu, i slušaju Boga, duša po zakonitu poretku vlada tijelom a razbor porocima), da kao što pojedini pravednik isto tako i skup i narod pravednih živi iz vjere što djeluje po ljubavi, kojom čovjek ljubi Boga - kao što Boga treba ljubiti - i bližnjega kao sebe sama - gdje, dakle, nema takve pravednosti, zaista nema ni 'skupa ljudi udruženih zajedničkim osjećajem prava i zajedničkom koristi.' Ako toga nema, onda nema ni naroda, ako je točan onaj spis i odredba naroda. Pa tako, nema ni države, jer nema stvari naroda ondje gdje nema samoga naroda. $\ll^{35}$

Augustin je u dualizmu dviju država odredio objema svrhe i to na temelju odnosa ljubavi frui (uživanja) i uti (upotrebe), pri čemu je frui svojstvena državi Božjoj jer uživati znači držati neke stvari radi njih samih, dok upotrebljavati znači dovoditi stvari u odnos s onim što se voli radi ozbiljenja toga predmeta ljubavi. Dakle, opravdano je postojanje političkoga i zemaljske države, ali samo upotrebno (uti) radi ozbiljenja više svrhe, života u Božjoj državi. Poštovanje Boga ne znači samo vjeru, nego, prije svega, izlazak iz vlastita egoizma i mogućnost usmjerenosti drugomu, odnosno ukazuje na najveći nedostatak zemaljskih poredaka, a to je samoljublje

${ }^{33}$ Coleman tvrdi da je tema dviju država, Božje i ljudske, dominirala političkom teorijom tijekom idućih 800 godina srednjega vijeka i nakon toga. Usp. J. COLEMAN, Augustin iz Hippa, u: D. MILER (ur.), Blackwellova enciklopedija političke misli, Zagreb, 22.-26.

${ }^{34}$ AURELIJE AUGUSTIN, O državi Božjoj, II, Zagreb, 1995., 303.

${ }^{35}$ Isto, III, Zagreb, 1996., 81. 
koje proizvodi nepoštovanje ikakva vrhovništva. Augustin to pokazuje jednom od najznačajnijih misli kršćanske teologije, odnosno da:

»postoji nešto u poniznosti što na čudan način uzdiže srce, dok postoji nešto u uzdignuću što unizuje srce. Ovo se čini stanovitim protuslovljem što uzdignuće unizuje, dok poniznost uzvisuje. Ali, pobožna poniznost podvrgava nekoga višemu; a ništa nije više od Boga, te stoga uzvisuje poniznost koja podvrgava Bogu. Dočim, samo uzdignuće koje je po nedostatku, sâmo po sebi prezire podvrgnuće, pa otpada od onoga od kojega nije nitko viši i po tome biva niže $(. ..) \cdot \ll^{36}$

Augustin tako pokazuje kako je legitimnost zemaljske države neodrživa, osim u uporabnom smislu (uti), jer ona ne proizlazi iz težnje općem dobru svih dionika političke zajednice, stoga je individualistička težnja koja proizlazi iz samoljublja i ozbiljenja vlastitih interesa karakter zemaljske države i time pogubna za svoj opstanak. ${ }^{37}$

\subsection{TOMina Koncepcija okrenutosti Dobru}

Filozofija Tome Akvinskoga, osim po važnosti vlastitih postulata prilagodbe Aristotelove metafizike, važna je i po tome što usustavljuje znanje antičke filozofije i kršćanske misli, napose Augustinove, »zato je Tomu teško razumjeti ako se ne poznaju Platonova i Aristotelova filozofija te Augustinova teologija $\ll .^{38}$ Ovdje ne možemo ulaziti u Tomine teološke postulate, no potrebno je navesti samo neke koji se očituju u našoj tezi, onoj o odnosu političkoga s metafizičkim. Toma to aristotelovski postavlja tako da je predmet težnje neko dobro. Svako biće teži savršenstvu, a savršenstvo i forma učinak su neke sličnosti s onim koji ga je stvorio. Stvoreno sliči onomu koji ga stvara, stoga tvorac jest dobro, a time i predmet čežnje jer se teži sličnosti s njim. Prvi je uzrok i stvoritelj, te je predmet čežnje jer je dobro, po sličnosti mu biće teži. Budući da po Bogu sve postoji i tvorni je uzrok svega, može

\footnotetext{
${ }^{36}$ Isto, II, 271.

${ }^{37}$ Važno je kao primjer istaknuti kako Augustinova teološko-filozofska misao ima svoju primjenu u konkretnoj povijesnoj stvarnosti. Političko načelo koje je postavio papa Gelazije jasno je upućivalo na postojanje dviju različitih vlasti. Jedna je duhovna, koju je Krist povjerio svećenicima, a druga je vremenita, koja je povjerena carevima. Svaka od tih vlasti ima svoju ulogu i božanski izvor. Premda je razdvajanje tih uloga išlo u smislu prihvaćanja ljudskih slabosti s obzirom na težinu i zahtjevnost koju te službe stavljaju pred čovjeka, nužno je da su se u političkom i povijesnom smislu one susretale i ispreplitale. Premda je svaka od njih bila određena za jednu stvarnost i određivala se kao vrhovna u njoj, Gelazije je smatrao da je svećenička vlast veća jer je odgovorna Bogu i jer je bila uvjet za onu zemaljsku. Taj stav odredio je političku formulaciju Europe srednjega vijeka, a ta se pozicija još jasnije očitovala u Tominom razmatranju politike.

${ }^{38}$ U. MATZ, Toma Akvinski, u: H. MAIER, H. RAUSCH, H. DENZER (ur.), Klasici političkog mišljenja I., Zagreb, 1998., 108.-130., 108.
} 
se zvati dobrim. Savršenstvo kojem se teži proizlazi iz udioništva i sličnosti s Božjim savršenostima i zbog toga, težeći za svojim savršenstvom, bića teže za Bogom koji je izvor svakoga savršenstva. Stoga su savršenstva bića određene sličnosti s Božjim bitkom. Naime, Bog je Dobro. Toma to pokazuje u skladu s antičkom filozofijom prema kojoj nije istoznačno biti i biti Dobro, što su razmatrali Platon i Augustin uz presudnu razliku da kod Augustina to nije samo ontološki status bića, nego i voljni akt bitka. Stvari koje postoje i koje su složene ne bi mogle postojati bez volje jednostavnoga bića koje je Prvo Dobro:

»Naime, budući da Prvo Dobro jest, time što jest, jest dobro. Naprotiv, drugo dobro je dobro zato što je poteklo od onoga čiji je sam bitak dobro. No bitak svih stvari potekao je od onoga koje je prvo dobro i koje je takvo dobro te se ispravno o njemu kaže da je dobro time što jest. Prema tome njihov je bitak dobar. Doista, time što bi postojale, ne bi bile dobre da nisu potekle od Prvog Dobra. $\ll^{39}$

Budući da je dobro najosnovnija danost, nema osnovnije ili jednostavnije kojom bismo ga objasnili, zato se dobro, jer pokreće ljudske težnje, objašnjava iz učinaka koje te težnje ostvaruju. Djelovanje nam služi da bismo objasnili neko dobro, a ne obratno, da bismo dobrim objašnjavali djelovanje. Dobro je osnovna danost, uzrok i uvjet bića te se s njime i podudara. To znači da je u osnovi bića nužno prisutno dobro po sebi, po bîti. Bez toga dobra po sebi nema bića. Dobro kao uzrok bića jest ono bez čega biće ne može. Time Toma pokazuje kako je biće za razliku od stvorenih stvari ujedno i dobro kao Dobro jer je jednostavan, jedan. Iz bića koje je dobro može proizlaziti samo pravednost, pa je samo Bog pravednost sama. U postulatu pravednosti, što je kod Tome odlučujuće Augustinovo, nije važna bît, kao kod Dobra (ono jest), nego volja (koja treba biti) koja se u Tome često izjednačuje s pravednošću, i zato pokazuje kako biti dobar, koji se dakle tiče bîti, ne pretpostavlja biti pravedan, koji se tiče činidbe. Razlog je u tome što je u Bogu isto biti dobar i biti pravedan, a u ljudi to nije slučaj jer $\gg \mathrm{u}$ nama pak nije isto bitak što i djelovanje; mi naime nismo jednostavni. Nije dakle u nama isto 'biti dobar' što i 'biti pravedan', ali bitak pripada svima nama time što jesmo; prema tome sve su stvari, uključivši i nas, dobre, ali ne i pravedne $\ll .{ }^{40}$ Složena bića imaju svoju bît prema sudjelovanju, udioništvu u Božjoj bîti, zato ona ne mogu biti dobra u svojoj bîti, tj. dobra po sebi, jer bitak imaju po udioništvu. Dobrota mu je dodana. Stoga je jedino Bog kao jednostavno biće dobar po svojoj bîti jer je jedino on onaj kojemu je jedno bit i bitak.

Time je vidljivo Augustinovo razmatranje o slobodnoj volji jer je odlučujuće to da čovjek, prepušten sebi, vlastitom voljom treba djelovati prema Dobru, kao čin

\footnotetext{
${ }^{39}$ TOMA AKVINSKI, Izabrano djelo, Zagreb, 1996., 392.

${ }^{40}$ Isto, 402.
} 
ljubljenja višega dobra, jer sama bît čovjeka ne pretpostavlja pravednost po sebi, nego po djelovanju s obzirom na to da u čovjeku bit i bitak nisu jedno kao u Boga. U Bogu su, dakako, bitak i trebanje izjednačeni jer je Bog time što jest ujedno i ono što treba biti, a čovjek time što jest može mijenjati svoju narav voljnim okretanjem prema Bogu kao Drugomu, a time i prema drugomu čovjeku kako bi ispunio svoju svrhu djelovanja za zajedničko dobro.

Važnost navedenoga očituje se u praktičnom ostvarenju. Naime, u potpunosti preuzimajući Aristotelove argumente, za Tomu je najsavršenija zajednica državna zajednica, odnosno $\gg$ država $\ll{ }^{41}$, stoga je okrenutost drugomu kao onomu zajedničkomu odlučujuća za političko jedinstvo. Otuda je cilj ono zajedničko dobro kao supstrat svake političke zajednice, a njemu se dolazi apodiktičkim postulatom usmjerenosti Bogu kao vrhovnom dobru. Toma pokazuje kako se ljudsko djelovanje odnosi na pojedinosti, ali se one mogu usmjeriti prema zajedničkom dobru i to na način zajedništva svršnoga uzroka, »ukoliko se zajedničko dobro naziva zajedničkim ciljem $\ll{ }^{42}$ Iz istoga slijedi da zakon može donositi samo cjelina radi cjeline, odnosno cijeli narod (totius multitudinis) ili njegov predstavnik, jer $\gg \mathrm{u}$ tom smislu svatko je sam sebi zakon, ukoliko naime ima udjela u poretku nekoga upravitelja «. ${ }^{43}$ Za vertikalan i horizontalan odnos u pretpostavci je prijateljstvo, odnosno postulat ljubavi prema drugima, jer u političkoj zajednici, kao i u međuljudskim odnosima, odlučujući je stupanj povjerenja prema drugomu. Iz toga proizlazi, kako pokazuje Toma, da je takav zakon upisan u njihovim srcima. Na isti se način, kao i u kozmološkom poretku, i dobro bilo kojega dijela ocjenjuje u odnosu na njegovu cjelinu:

»Budući je, dakle, svaki čovjek dio države, nemoguće je da neki čovjek bude dobar ako nije dobro usklađen sa zajedničkim dobrom, a isto tako cjelina ne može biti dobro sastavljena ako joj dijelovi nisu usklađeni. Stoga je nemoguće da zajedničko dobro države bude postojano (bene se habeat), ako građani nisu kreposni, u najmanju ruku oni na koje spada da vladaju. $\ll^{44}$

Naime, pravedno je za Tomu ono što je usmjereno općosti ili općemu (zajedničko$\mathrm{mu}$ ) dobru, stoga i ljudski zakon ne određuje sva djela svih krjeposti, nego samo ona koja su usmjerljiva prema zajedničkomu dobru. Kako je za Tomu, kao i za Aristotela te Augustina, cjelina savršenija od dijela te time zajednica savršenija od pojedinca, svaki čovjek po onome što jest i što ima pripada narodu kao cjelini mnoštva (multitudinis). Upravo zbog toga, primjećuje Toma, može se dogoditi da se čini

\footnotetext{
${ }^{41}$ Usp. isto, 466.

${ }^{42}$ Isto, 467.

${ }^{43}$ Isto.

${ }^{44}$ Isto, 478.
} 
nepravda pojedincu zbog očuvanja cjeline, stoga imaju snagu samo oni zakoni koji razmjerno raspoređuju terete, što je, dakako, preuzimanje Aristotelove mješovite vladavine (ustava) po uzoru na harmoniju kozmosa.

U analizi ljudskih zakona (za razliku od Božjega i prirodnoga zakona) Toma dolazi do odlučujućega argumenta, a to je podložnost takvomu zakonu postavljenom u pitanju obvezuje li zakon zakonodavca, odnosno vladara. Za Tomu vladar ne može biti obvezan zakonom koji sam donosi po prisilnom karakteru zakona (vis coactiva) jer nitko ne može prisiliti samoga sebe na nešto. Međutim, obvezan je Božjim zakonom po usmjeriteljskom karakteru (vis directiva), koji nalaže vladaru podvrgavanje vlastitim zakonima, stoga na taj način vladar ipak jest obvezan vlastitim zakonima jer bi u protivnom nastupila tiranija kao neželjeno izvrgavanje kraljevske vlasti protivno Božjemu zakonu. ${ }^{45}$ Međutim, u svakoj političkoj zajednici postoji skrbnik (vladar) koji ipak ne podliježe ljudskim zakonima, kakav je i njegov, nego samo Božjim zakonima. Izuzeće od zakona nije bez ograničenja, ono je, ponovno metafizički, ograničeno svrhom djelovanja višem dobru, odnosno zajedničkom dobru i razlogom samovolje koji je zabranjen.

Odlučujuće je po pojam univerzalnoga dobra i ljubavi te prijateljstva kao povezanosti dionika političke zajednice to da za kršćansku metafizičku misao, a time i političku, taj odnos počiva na univerzalnome humanizmu. Stoga je i važno Tomino razmatranje postoji li samo jedan božanski zakon. Dakako, kršćanski teolog Toma, po uzoru na Augustina, Stari zavjet (savez) određuje kao onaj koji je nesavršen i partikularan jer se odnosi samo na Izrael (Židove), dok je Novi zavjet (savez) savršen i univerzalan jer se odnosi na sve ljude. Novi zavjet nadmašuje samim time i Stari zavjet po pitanju pravednosti, pri čemu navodi Matejeve novozavjetne riječi: »ne bude li pravednost vaša veća od pismoznanaca i farizejâ, nećete ući u kraljevstvo nebesko.« Stoga se kaže, navodi Toma, da Stari zakon obuzdava ruku, a Novi zakon dušu, odnosno da se Stari zavjet temelji na strahu od kazne, a Novi zavjet na

${ }^{45}$ Usp. isto, 510. Zanimljivo je kako će u novovjekovnoj filozofiji politike, napose Hobbesovoj, Levijatan biti oslobođen obveze podvrgavanja vlastitom zakonu jer on ne ugovara ni sa kim kako bi trajno ostao izvan ugovora i time jamčio mir i sam ugovor. Kasnije će se razviti i doktrina raison d'êtat prema kojoj država ne odgovara zakonima na jednak način kao i državljani. Zarka pokazuje kako Hobbesova teorija autorizacije onemogućuje pokoravanje vlastitim zakonima jer je svaki pojedinac (građanin) autorizirao (ovlastio) sve radnje suverena kao vlastita djelovanja, pa bi obveza suverena bila po sebi proturječna. Zarka pokazuje kako takav uzajamni sporazum podrazumijeva dvostruko obvezivanje; međusobno između podanika i s osobom na koju su prava prenesena. Usp. Ch. Y. ZARKA, Hobbes et la pensée politique moderne, Paris, 2001., 203. 
praštanju i ljubavi, o čemu će se voditi mnoge, prije svega, filozofske rasprave po pitanju obligacijske snage dvaju saveza. ${ }^{46}$

Tomino razmatranje političkih implikacija metafizičkoga postulata Boga i njegovih atributa vidljivo je i u pitanju o pravu i pravednosti. Naime, Toma razmatra razlikovanje javnoga, odnosno pozitivnoga (političkoga) prava od privatnoga prava. Koristeći se Aristotelovom postavkom kako je politička pravednost dijelom prirodna, a dijelom zakonska, Toma pokazuje kako pravednost jest jednakost ili razmjer koji se može postići prirodnim putem prema vlastitoj naravi onih koji se međusobno odnose ili međusobnim ugovorom sudionika. Pristanak naroda na određeni koncept pravednosti pretpostavlja društveni ugovor onih čija je volja pravedna, odnosno teži zajedničkome dobru. Međutim, kako je ljudska narav promjenjiva, događa se da se ljudska volja izopači, odnosno djeluje samo u vlastitu korist, suprotno zajedničkomu dobru, a onda pozitivno (političko) pravo ima snagu zakona koji djeluje suprotno zloj naravi čovjeka. Na taj način Toma, što je presudno, nepravednost određuje kao preziranje zajedničkoga dobra, odnosno zajedničke volje svih članova zajednice za pravednošću.

Pravednost se stoga odnosi i na vertikalnu (potentia ordinata) i na horizontalnu društvenu razinu među ljudima. Stoga Toma i naglašava kako je pravednost uvijek usredotočena na odnose prema drugima, što je preduvjet opstojnosti svake političke zajednice, sukladno sa zajedništvom koje je mnoštveno (Aristotel), odnosno da je politička zajednica poredak različitosti koju treba uskladiti po uzoru na kozmički poredak harmonije. Zbog toga su za Tomu, kao i za Platona, Aristotela te biblijsku tradiciju, moguće one političke zajednice koje počivaju na četirima temeljnim krje-

\footnotetext{
${ }^{46}$ Treba napomenuti da će Hobbes primjerice upravo svoje teze temeljiti na kritici Novoga zavjeta upravo zato što ne počiva na partikularnom ugovornom odnosu kao Stari zavjet, pa stoga ni nema snagu zakona, nego samo savjeta. Ugovor (savez) mora biti partikularan, odnosno ustvrditi strane ugovora. Hobbes primjećuje da se prema stilu poslanica može razaznati i metafizička razlika između dvaju Zavjeta. Naime, dok je Stari zavjet (zakon) pisan kao da proroci govore u ime Boga (npr. Ovako kaže Gospod, Gospod nad vojskama reče, riječ Božja itd.), u Novom zavjetu, u poslanicama apostola takvoga čega nema jer često susrećemo neodlučne izjave karakteristične za savjetodavni karakter Kristova učenja (npr. mislimo, dakle, ja mislim, trebalo bi, ovo govorim po svome shvaćanju itd.). Stoga je važno primijetiti da apostoli neprekidno rasuđuju tako da izgleda da raspravljaju, a ne prorokuju. Proročanstva s druge strane sadrže samo čiste dogme i zapovijedi jer se Bog predstavlja kao da osobno govori, ne da bi raspravljao, nego da bi izdavao zapovijedi na temelju svoje apsolutne moći. Usp. TH. HOBBES, Leviathan, Or The Matter, Forme and Power of A Commonwealth Ecclesiasticall and Civil, New York, 2008. Ono što Hobbes nije uočio jest to da za Tomu Novi zavjet obvezuje duhovno, odnosno upisan je u srca podanika, stoga je to »činjenica da je Novi zakon Novog saveza. No zakon Novog saveza je usađen u srce « (isto, 521.). Za Tomu savjet koji je moralnoga karaktera, zapisan u srcu podanika ili vjernika, ima veću snagu nego bilo koja pozitivnopravna zapovijed zbog čega i zaključuje kako »savjet smjera na veće dobro nego zapovijed. Prema tome, više spada na zakon da savjetuje, nego da zapovijeda $\ll(i s t o, 479$.).
} 
postima, odnosno umjerenosti, razboritosti, pravednosti i hrabrosti. Tako je pravednost, sukladno s Aristotelom, cijela krjepost, a krjepost usmjeruje čovjeka, bilo prema sebi ili drugom čovjeku, uvijek prema zajedničkom dobru, a upravo je na to, pokazuje Toma, usmjerena pravednost jer je ona jedina krjepost koja može imati opće dobro (universalis boni). ${ }^{47}$

Presudno je, dakako, i na ovome mjestu vraćanje volji jer volja određuje djelovanja podanika prema višem dobru:

$\gg$ Kao što djelatnosti prirodnih stvari proizlaze iz prirodnih sila, tako i ljudske djelatnosti proizlaze iz ljudske volje. U prirodnih stvari potrebno je da ono što je više, po višoj prirodnoj sili koju mu je Bog dodijelio, pokreće u njegovim djelatnostima ono što je niže. Stoga je i u ljudskih stvari potrebno da viši, po snazi božanski ustanovljena autoriteta, svojom voljom pokreću niže. A pokretati razumom i voljom znači zapovijedati. I zato, kao što se po božanski utvrđenom prirodnom redu, stvari u prirodi nužno moraju podvrći tome da ih pokreće ono što je više, upravo tako u ljudskim odnosima, u skladu s naravnim i božanskim pravom, niži trebaju biti poslušni višima. $\ll^{48}$

Takva volja nije u potpunosti postavljena u duhu Augustinovih postulata jer Toma piše da htijenje prema višem dobru ne može biti nužno, nego voljno, ali u poretku voljâ Božja volja, kao i volja starješine, uvijek je po rangu nadređena pojedinačnoj volji podanika, čime utemeljuje hijerarhijski poredak subordinacije voljâ. Božja volja kao opća najbolji je upravitelj pojedinačnim voljama. Na isti je način volja starješine obveza volji pojedinca, odnosno podložnika, jer jedino na taj način usklađene volje, poput božanskoga poretka kozmosa, vode zajedničkomu dobru (općemu dobru). ${ }^{49}$

Čovjek je po prirodi upućen na političku zajednicu, stoga je i prirodno da postoji netko tko će društvom upravljati i vladati jer bi se »raspalo tijelo čovjeka ili bilo koje životinje kad u tom tijelu ne bi postojala neka zajednička vladajuća sila koja se brine za zajedničko dobro svih udova $\ll^{50}$. Sada Toma na istome mjestu razmatra

\footnotetext{
${ }^{47} \gg$ S obzirom na to, čini svih kreposti mogu pripadati pravednosti, jer ona usmjerava čovjeka na zajedničko dobro. U tom smislu pravednost se naziva općom kreposti. Budući da zakon ima u vidu zajedničko dobro, kao što je već rečeno, slijedi da se takva pravednost u općem smislu naziva zakonskom pravednošću, jer ona čovjeka usklađuje sa zakonom koji čine svih kreposti usmjeruje prema zajedničkom dobru.« (Isto, 584.)

${ }^{48}$ Isto, 655.

${ }^{49} \mathrm{Za}$ utjecaj kršćanskoga pojma volje na novovjekovnu filozofiju politike, usp. G. SUNAJKO, Metafizika i suverenost, Zagreb, 2015.

${ }^{50}$ TOMA AKVINSKI, Država, Zagreb, 1990., 51.
} 
zemaljski politički poredak po uzoru na kozmološku raspravu u Sumi teologije te pokazuje kako se zajedničko i privatno razlikuje tako da se po privatnome ljudi razlikuju, a po zajedničkome ujedinjuju. Stoga su, pokazuje Toma, dvije Božje djelatnosti u svijetu. Prva kojom svijet sazda, a druga kojom sazdanim svijetom upravlja. Te su djelatnosti metafizičke jer ih ima i duša u tijelu s obzirom na to da se prvo snagom duše oblikuje tijelo, a zatim duša upravlja tijelom i pokreće ga, što je u potpunosti antičko gledište. Kako je političko zajedništvo najbolje od svih, prirodna je zadaća svakoga kralja da ponajprije osnuje kraljevstvo (političku zajednicu) kako bi svaki pojedinac mogao ispuniti svoju svrhu zajedničkoga života u prijateljstvu. Ona u zemaljskome životu vodi miru, a u nebeskome blaženstvu. ${ }^{51}$ Prijateljstvo je vezano uz brigu o zajedničkom dobru, a vlast, ako je usmjerena općem dobru, stvara pretpostavke za postizanje prijateljstva između, u ovom slučaju, kralja i podanika, što je jedno od najvećih i najvrjednijih ovozemaljskih dobara. Dobro vladanje donosi dobrim vladarima i zemaljske probitke, uz one nebeske, vječne. Budući da je vladanje jedan proces, nužna je samokontrola vladara kako bi izbjegli zamku da postanu tirani. Svjetovno dobro koje Toma ističe i uzdiže iznad svakoga drugoga jest prijateljstvo.

»Ono, naime, ujedinjuje kreposne ljude, čuva i promiče krepost. Ona je potrebna svima u vršenju kog drago mu posla i ne stvara neprilike sretnicima niti ostavlja u neprilikama one koji su u neprilikama. Ona donosi najveće užitke i to u tolikoj mjeri da bez prijatelja, koji god mu dragi, užici postaju dosadni. $\ll^{52}$

\section{Zaključak}

Razmatranje političkoga, koje je u novovjekovnoj politici poprimilo sasvim drukčije razmjere, osobito oblikovanjem pojma države kao novovjekovnoga oblika političke zajednice te sve većim utjecajem racionalizma i nužnosti isključenja morala iz politike (Machiavelli, Hobbes), zanemarilo je prednovovjekovne pokušaje izgradnje političkoga svijeta na metafizičkim, kozmološkim načelima sklada, dobra, ljubavi i prijateljstva. Te kategorije međutim, prema njihovim zastupnicima, tek omogućuju kolektivnu egzistenciju ljudi u političkom zajedništvu, a utemeljene su na metafizičkim načelima kakvima je u mišljenju uređen poredak kozmosa u okviru grčke filozofije te okrenutost višemu dobru kao onomu drugomu sebi u latinskim teološkim postulatima. Radom smo, izostavljajući ambiciju obuhvaćanja dubljega i širega razmatranja te teme, nastojali samo naznačiti važnost prednovovjekovnih načela koja na metafizičkim postulatima otvaraju put onim političkim. Imajući u

\footnotetext{
${ }^{51}$ Usp. isto, 100.

${ }^{52}$ Isto, 88.
} 
vidu Aristotelov naputak kako »metafizika nije namijenjena za ljudsku upotrebu «, prikazali smo one dijelove koje i sami navedeni mislioci određuju kao spoj metafizičkih i praktičnih odnosa. Na temelju Platonovih i Aristotelovih te Augustinovih i Tominih stajališta, koja se mogu pratiti i kao dvije struje mišljenja (Augustinov platonizam i Tomin aristotelizam), pokazalo se odlučujućim to da je čovjekov život nužno okrenut njegovoj izvanjskosti, kao onomu drugomu kojem je okrenut posredstvom Dobra, ljubavi i prijateljstva kao temeljima njegova života koji ga upućuju na njegovu puninu. U konačnici, čovjek nije Bog da bi u svojoj savršenosti bio okrenut samome sebi kao apsolutu. U njemu, kako smo vidjeli s Tomom, bit i bitak nisu jedno, što znači da je on nužno usmjeren izvanjskomu kao savršenstvu kojem svojom voljom teži. Time se prevladava okrenutost sebi iz gnoseoloških razloga s jedne strane i antropoloških s druge strane.

Važno je napomenuti ono što nije moglo biti dio ovoga rada, a to je razvoj filozofije Drugoga koja je na temelju kršćanske recepcije antičke filozofije zaživjela u moderni, napose u 20. stoljeću. Tako je važno imati na umu da je Descartesova filozofija koja utemeljuje novi vijek zadržala poziciju Boga kako bi on bio ona čovjekova nužna izvanjskost da bi se on sam potvrdio u svojoj egzistenciji, kao ono nužno drugo ja kroz koje sam siguran da jesam. Rousseauova pozicija ljubavi prema drugome kroz empatiju i Kantova pozicija prijateljstva kao moralne dužnosti pokazale su onu presudnu drugotnost u republikanskome ključu, a filozofija egzistencije i egzistencijalizam čovjekov bitak koji se ispunjava u svijetu. Arendt je pisala o važnosti ljubavi i vita activa, Levinas o licu Drugoga, kao i Ricoeur o sebstvu kao drugotnosti. Osobito je važno izdvojiti nastojanje Jacquesa Derridaa koji se kritički odnosi spram kršćanskoga utjecaja samo kako bi pokazao da onaj drugi treba ostati takav u svojoj drugotnosti, odnosno ne smijemo obogotvoriti čovjeka jer bi to značilo tražiti ga da se mijenja i odbaciti ga u onome kakav on doista u svojoj drugotnosti jest. Sve te pozicije, koje su samo izdvojen dio, a koje ovdje ne možemo tematizirati, političke su te imaju važnu poveznicu s načelima koja smo postavili radom. Suvremena politika odbacuje metafizičke pristupe, dakako, jer se svaka metafizika, kako je pokazao Nietzsche, uspostavlja kao cjelina istine. No ono što rad pokazuje jest njezinu važnost koja je u postavkama o okretanju ili usmjeravanju onomu čovjeku transcendentnom, izvanjskom kao pretpostavci koja tek omogućuje društveni i politički život koji treba nadilaženje partikularnosti i solipsizma da bi ono opće ili javno bilo moguće. Tomu čovjek izlazi iz vlastite imanencije sa sviješću o drugome. Može se reći kako je tek tada moguće zasnivanje intersubjektivnosti kako su to sugerirali Husserl $\mathrm{u}$ fenomenološkom, Popper $\mathrm{u}$ epistemološkom i Habermas u komunikološkom smislu. Metafizičke pozicije koje smo samo dijelom istaknuli pokazuju upravo čovjeka bićem koje je nužno okrenuto drugomu i tek je takvo zoon politikon. Ostvarenje političke zajednice moguće je ako se prihvati sveukupnost 
čovjekova postojanja kao ono što je nužno stavljeno u čovjekovu izvanjskost kao transcendirajuću imanentnost koja ga usmjerava drugomu kao dobru, prijatelju i objektu ljubavi. Iz toga odnosa prijateljstva i ljubavi kojima su naravi ono drugotno politika, kao i politička zajednica, shvaćena kao najviši oblik ljudskoga udruživanja, dobiva svoj smisao i opravdanje. Dobro kao uzrok i svrha otkriva se u drugome kao svrsi čovjekove egzistencije. 


\title{
THE METAPHYSICAL ORIENTATION TOWARDS THE OTHER AS THE FOUNDATION OF THE POLITICAL IDEA OF COMMUNITY
}

\author{
Goran SUNAJKO - Ratko PODVORAC*
}

Summary: The aim of this paper is to discuss the importance of metaphysics for the questions of good and friendship as preconditions for the social and political community. It is obvious that the idea of friendship today is seriously impaired by interest and egoistic postulates based on material existence, therefore, it is necessary to put the question on existence into its metaphysical frameworks of orientation towards the Other, which is the fundamental substratum of Christian metaphysics based on Plato's and Aristotle's postulates. The paper will focus on Plato's, Aristotle's, Augustine's and Thomas' insights which open up the possibility of thinking of the Other as a precondition of a philosophy and politics of friendship. The aim of the paper is only to indicate some relationships that connect the metaphysical and political insights about the importance of the idea of good and friendship as a precondition of openness to others and thus the possibility of achieving any form of community.

Keywords: Plato, Aristotle, Augustine, Thomas Aquinas, good, friendship, egoism, political community.

\footnotetext{
* Asst. Prof. Goran Sunajko, Ph. D., The Miroslav Krleža Institute of Lexicography, Frankopanska 26, 10000 Zagreb, Croatia; Faculty of Humanities and Social Sciences, University of Zagreb, Ivana Lučića 3, 10000 Zagreb, Croatia, goran.sunajko@lzmk.hr

Ratko Podvorac, M. Theol., postgraduate, Catholic Faculty of Theology, University of Zagreb, Vlaška 38, 10000 Zagreb, Croatia, diaconusrp@gmail.com
} 